\title{
Composition of Cachaças Produced from Five Varieties of Sugarcane and the Correlation of the Presence of Dhurrin in the Cane with That of Ethyl Carbamate in the Product
}

\author{
Francielli D'Carlos Cravo', Wilder Douglas Santiago², Allan da Silva Lunguinho², \\ Richard Bispo Barbosa ${ }^{2}$, Renan Elan da Silva Oliveira1, Gabriela Fontes Alvarenga1, \\ Stephano Daniel Santos ${ }^{2}$, Rafaella Hilda Zaniti Souza ${ }^{1}$, Ellen Cristina de Souza1, \\ Katia Julia de Almeida², Josefina Aparecida de Souza², David Lee Nelson³, \\ Maria das Graças Cardoso ${ }^{2 *}$

\footnotetext{
${ }^{1}$ Department ofFood Science, Federal Universityof Lavras, C.P. Lavras, Minas Gerais, Brazil

${ }^{2}$ Department of Chemistry, Federal University of Lavras, C.P. Lavras, Minas Gerais, Brazil

${ }^{3}$ Pro-Reitoria de Pesquisa e Pós-Graduação, Federal University of Vales de Jequitinhonha and Mucuri, Diamantina, MG, Brazil

Email: *mcardoso@ufla.br
}

How to cite this paper: Cravo, F.D., Santiago, W.D., da Silva Lunguinho, A., Barbosa, R.B., da Silva Oliveira, R.E., Alvarenga, G.F., Santos, S.D., Souza, R.H.Z., de Souza, E.C., de Almeida, K.J., de Souza, J.A., Nelson, D.L. and das Graças Cardoso, M. (2019) Composition of Cachaças Produced from Five Varieties of Sugarcane and the Correlation of the Presence of Dhurrin in the Cane with That of Ethyl Carbamate in the Product. American Journal of Plant Sciences, 10, 339-350.

https://doi.org/10.4236/ajps.2019.102025

Received: December 19, 2018

Accepted: February 24, 2019

Published: February 27, 2019

Copyright $\odot 2019$ by author(s) and Scientific Research Publishing Inc. This work is licensed under the Creative Commons Attribution International License (CC BY 4.0).

http://creativecommons.org/licenses/by/4.0/

\begin{abstract}
The present work sought to characterize the cyanogenic glycoside dhurrin in five sugarcane varieties and to determine its possible relationship with the formation of ethyl carbamate in cachaça. For each variety, methanol, ethyl acetate and hexane extracts were prepared and submitted to thin layer chromatography. Chromatographic spots were revealed with iodine vapors. The physical and chemical parameters of the spirits produced from the five different varieties of sugar cane and by different production processes were within the legal limits. Although not exceeding the limit for ethyl carbamate, a significant variation in the final concentration of this compound was observed for each sample analyzed. The $\mathrm{R}_{\mathrm{f}}$ values for the dhurrin standard and for the sugarcane variety SP 83-2847 were equal, similar to those for SP 80-3280 and CTC 11 and different from the $\mathrm{R}_{\mathrm{f}}$ values for the RB 86-7515 and IAC 86-2480 samples.
\end{abstract}

\section{Keywords}

Cachaça, Ethyl Carbamate, Quality, Glycosides, Cyanide, Dhurrin

\section{Introduction}

Cachaça is currently the most widely consumed distilled beverage in Brazil, and 
each cachaça has the methods of production and the cultural and historical characteristics of each region as a differential because they are produced in different localities. The standardization of cachaça is essential for the beverage to meet the standards required to increase sales and enable growth in exportation.

In addition to the secondary components, organic and inorganic residual contaminants can be formed throughout the production chain. Among the organic contaminants, ethyl carbamate has been widely studied because it is an obstacle to exports and because it is potentially toxic. Little is known about the pathways of formation of this compound. The composition of the material to be fermented and the possible precursors present in the fermenting must can provide different pathways for its formation. One of the routes proposed for formation of ethyl carbamate during fermentation is that involving compounds having the cyanide $\left(\mathrm{CN}^{-}\right)$ion in their composition. This ion is formed by the enzymatic action and thermal cleavage of cyanogenic glycosides, compounds that might be present in sugarcane and that, when oxidized, form the cyanate ion $\left(\mathrm{HCNO}^{-}\right)$, which can react with alcohol to form ethyl carbamate.

Cyanogenic glycosides might be present in cyanogenic plants of many families, such as Rosaceae, Poaceae, Leguminoseae, Gramineae, Araceae, Passifloraceae and Euforbiceae. In these plants, the $\mathrm{HCN}$ is bound to carbohydrates, and it is released after hydrolysis. It is believed that more than 2650 species of plants of more than 550 genera and 130 families are cyanogenic [1].

Cyanogenic glycosides are water soluble, and they are produced by the secondary plant metabolism. They are located in the cellular vacuole, where their main function for the plants is defensive. The enzymes that degrade glycosides are found in the cytoplasm. A possible mechanical damage to the plant tissue containing cyanogenic glycosides, such as cutting, grinding or chewing, breaks the cell vacuole and cytoplasm, resulting in degradation of the glycosides by the sequential action of glucosidases and hydroxynitrilases and the release of hydrogen cyanide [2]. Most cyanogenic glycosides are derived from the five hydrophobic amino acids, tyrosine, phenylalanine, valine, leucine and isoleucine [3].

The sugarcane (Saccharum spp.) used for the production of cachaça, in its various varieties, is classified as a cyanogenic crop. However, the specific source of cyanide has not yet been elucidated. Because few studies have been performed that are related to the identification of these cyanogenic glycosides in different sugarcane varieties and their relationship with the formation of ethyl carbamate, research related to this compound and its routes of formation is important. The objectives of this study were to characterize the dhurrin cyanogenic glycoside by thin layer chromatography in different sugarcane varieties and to determine its possible relationship with the formation of ethyl carbamate in cachaças.

\section{Material and Methods}

The analyses were performed in the Laboratory of Analysis of the Quality of Spirits of the Department of Chemistry of the Federal University of Lavras during the year 2017. 


\subsection{Collection of Samples}

Five hundred grams of each of five different sugarcane varieties were collected in different regions of the states of Minas Gerais and São Paulo. These varieties were used in two different types of agroindustrial processing: sugarcane for the production of distilled spirits in stainless steel columns and sugarcane for production of cachaça in copper stills. In addition to the samples of sugarcane, samples of the spirits produced from the sugarcane were collected without being stored or aged. The sugarcane varieties (source region, the types of fermentation and distillation of the selected spirits) were the following: RB 86-7515 (Perdões, MG; selected yeast; copper alembic); SP 83-2847 (Divinópolis, MG; wild yeast; homemade; corn meal; copper alembic); IAC 86-2480 (Pimenta, MG; wild yeast; homemade; corn meal, copper alembic); SP 80-3280 (Piracicaba, SP; selected yeast; stainless steel column) and CTC 11 (Piracicaba, SP; selected yeast; stainless steel colum).

\subsection{Obtaining the Crude Exracts}

The sugarcane samples were sanitized with $5 \%$ sodium hypochlorite solution containing $100 \mathrm{ppm}$ ( $2 \mathrm{~mL}$ of $\mathrm{NaOCl} / \mathrm{L}$ of water) [4]. The samples were immersed in the sanitizing solution, and after ten minutes, they were rinsed in flowing drinking water. The samples were ground in a Marconi ${ }^{\circledR}$ model MA345/H grinder and stored frozen.

The crude extract was obtained by weighing $70 \mathrm{~g}$ of each sample on an analytical balance (Gehaka ${ }^{\oplus}$, model BG 1000). Each sample was placed in a round bottom flask coupled to a reflux condenser and heated under slow reflux for $8 \mathrm{~h}$ using $200 \mathrm{~mL}$ each of three different solvents: ethanol, hexane and ethyl acetate. The samples were filtered on a Büchner funnel, discarding the cake, and the solvent was evaporated on a Buchi ${ }^{\oplus} \mathrm{R}-114$ rotary evaporator under reduced pressure.

\subsection{Chromatographic Analysis of the Extracts}

For the thin layer chromatography of the extracts, chromatographic plates were prepared from Silica Gel 60G, $245\left(\mathrm{Merk}^{\circledR}\right)$. The extracts, together with the standard solution of dhurrin (Sigma standard), were analyzed by TLC using a 7:3 mixture of methanol and ethyl acetate. The plates were visualized in an iodine atmosphere.

\subsection{Physicochemical Analyzes of Spirits}

The analyses of the samples were accomplished according to the specifications established by the Normative Instruction no. 24 of 08/09/2005 of MAPA [5]. The parameters analyzed were alcohol concentration, volatile acidity, esters, aldehydes, higher alcohols, furfural, methanol, copper, and dry extract. The quantification of ethyl carbamate was performed accordint to the methods of Anjos et al. [6], Machado et al. [7] and Santiago et al. [8]. 
The alcohol concentration was determined by distilling $250 \mathrm{~mL}$ of each of the samples, and the alcohol concentration of the distillate was measured using a DensiMat Gibertini electronic densitometer at $20^{\circ} \mathrm{C}$. The volatile acidity was determined by the extraction of the volatile acids by steam disitllation using an Enochimico Gibertini electronic distiller. The distillate was titrated with $0.1 \mathrm{~mol} \cdot \mathrm{L}^{-1}$ $\mathrm{NaOH}$ in the presence of $1 \%$ phenolphthalein. The results were expressed in milligrams of acetic acid per $100 \mathrm{~mL}$ of anhydrous alcohol.

Esters were determined by saponification of the samples. After acidifying the solution, the liberated acids were distilled, and their concentration in the distillate was measured by titration with $0.1 \mathrm{~mol} \cdot \mathrm{L}^{-1} \mathrm{NaOH}$.

The aldehyde concentration was determined by iodometric methods, in which the $\mathrm{SO}_{2}$ produced during the sequence of reactions involved in this type of analysis was titrated. The amount of aldehydes present in the samples was expressed in grams of acetaldehyde per $100 \mathrm{~mL}$ of the sample or per $100 \mathrm{~mL}$ of anhydrous alcohol.

Higher alcohols were determined by the addition of p-dimethylamino-benzaldehyde (DMAB) and subsequent acidification of the samples with concentrated sulfuric acid. The total concentration was determined by means of spectrophotometric measurements at $540 \mathrm{~nm}$ using a Shimadzu UV-1601 PC spectrophotometer. The concentrations of this compound were determined by constructing analytical solution curves of higher alcohols dissolved in 1:1 (v/v) water/ethanol. The total concentrations of these compounds were expressed in milligrams per $100 \mathrm{~mL}$ of anhydrous alcohol.

Methanol was determined by spectrophotometric measurements at $575 \mathrm{~nm}$ using a Shimadzu UV-1601 PC spectrophotometer after addition of 3\% potassium permanganate and subsequent cooling of the samples. The determination is based on the oxidation of methanol to formaldehyde, which reacts with chromotropic acid in the presence of concentrated sulfuric acid to form a colored product. Quantities were determined by constructing analytical curves of ethanol/methanol solutions.

The quantification of furfural and hydroxymethylfurfural was accomplished by the addition of aniline and glacial acetic acid to the samples, followed by spectrophotometric measurements at $520 \mathrm{~nm}$ using a Shimadzu UV-1601 PC spectrophotometer. The concentrations of this compound were determined by constructing analytical curves of standard furfural solutions in ethanol. The results were expressed in milligrams of furfural per $100 \mathrm{~mL}$ of anhydrous alcohol.

The analysis of copper was achieved by means of spectrophotometric measurements at $546 \mathrm{~nm}$ (Shimadzu UV-1601 PC) and comparing the absorbances to a previously constructed analytical curve using copper sulphate as the primary standard. In this process, cupric ion was reduced to the cuprous ion, which formed a colored complex with the solution of 2,2-diquinolyl in isoamyl alcohol.

The dry extract was determined by evaporating a $25 \mathrm{~mL}$ aliquot of the undistilled sample in a tared capsule at $95^{\circ} \mathrm{C}$ for $3 \mathrm{~h}$, drying at $100^{\circ} \mathrm{C}$ for $30 \mathrm{~min}$ and 
cooling in a desiccator. The mass of solid residue was expressed in grams of dry extract per liter of the sample.

The high performance liquid chromatography technique described by Anjos et al. [6] for the analysis of ethyl carbamate, which requires the previous derivation of the sample, was employed. The equipment used was a Shimadzu HPLC, equipped with two Model SPD-M20A high pressure pumps, a model DGU-20A3 degasser, a model CBM-20A interface, and a model SIL-10AF automatic injector. To guarantee the analytical quality of the results, procedures for validation of the method were performed. The reagents used for analysis were the ethyl carbamate standard, absolute ethanol, propanol, hexane, hydrochloric acid, sulfuric acid, methanol, glacial acetic acid, sodium acetate, HPLC-grade acetonitrile (Merck), ultrapure water and 9-xanthydrol.

\subsection{Statistical Analyses}

A completely randomized design was used in a scheme of plots subdivided in space. The data were submitted to analysis of variance, and the means were compared by the Tukey test at the $95 \%$ probability level using the SISVAR ${ }^{\circledR}$ statistical program [9].

\section{Results and Discussion}

\subsection{Physicochemical Analyses of the Cachaças}

The results obtained for the physicochemical evaluations of the cachaças and the respective varieties of sugarcane from which they were produced are presented in Table 1. All the samples of cachaças analyzed were clear and crystalline, suitable for conducting the analyses, without any solid impurity or turbidity. All the samples contained alcohol concentrations (Table 1 ) within the limits required to be denominated cachaça, ranging from $38.25 \%$ to $46.87 \%$ (v/v). Lower concentrations of alcohol were found in samples F1, F2 and F3, which were distilled in copper stills. The highest concentrations were observed in the samples F4 and F5, which were distilled in stainless steel columns and there was no separation of the fractions.

The results obtained for the analyses of volatile acidity (Table 1) all remained within the limits required by MAPA, which is $150 \mathrm{mg} / 100 \mathrm{~mL}$ of anhydrous alcohol. A general average of $31.65 \mathrm{mg} 100 \mathrm{~mL}^{-1}$ of anhydrous alcohol for volatile acidity was observed, with variations in the acidity of the cachaças produced throughout Brazil. According to Cardoso [10], the values for acidity in cachaças and other distilled sugarcane spirits can present large variations because several factors can interfere in this property, such as the lack of hygiene and the addition of citrus fruits to the must to be fermented, these being the principal factors that lead to an increase in acid concentration.

A high degree of acidity in cachaça can be attributed to the contamination of sugarcane or the must by acetic bacteria, which cause part of the substrate to undergo acetic fermentation, thereby increasing the acidity and decreasing the 
yield of ethanol. Ideally, the cane should not be stored for more than 24 hours after harvest to avoid contamination. Another factor described in the literature is the type of yeast used during the fermentation of the beverage. Silva et al. [11] studied compounds in cachaças produced by spontaneous fermentation by different types of yeasts and demonstrated that the acid concentration varied with the different strains of yeast.

All the samples analyzed contained concentrations of esters within the limit permitted (200 mg $100 \mathrm{~mL}^{-1}$ of anhydrous alcohol), ranging from 19.08 to 33.93 mg $100 \mathrm{~mL}^{-1}$ of anhydrous alcohol (Table 1). The principal ester found in cachaça is ethyl acetate, which, in suitable proportions, provides the beverage with a fruity aroma. Esters of higher alcohols can also be responsible for the taste and aroma of the beverage under the appropriate conditions [10].

The aldehyde concentrations found in all the samples studied are in accordance with the current legislation, which is $30 \mathrm{mg} 100 \mathrm{~mL}^{-1}$ of anhydrous alcohol [12]. A variation between 5.91 and $26.48 \mathrm{mg} 100 \mathrm{~mL}^{-1}$ of anhydrous alcohol was observed (Table 1), the latter value being considered high when compared to the other samples and very close to the maximum value required by the ABPM. Like most of the compounds present in the country's cachaças, the aldehyde concentrations can vary greatly. Cardoso et al. [13], analyzing 54 samples of cachaças from Minas Gerais, observed that the aldehyde concentrations varied from 5.52 to $33.93 \mathrm{mg} 100 \mathrm{~mL}^{-1}$ of anhydrous alcohol. Previously, Miranda et al. [14] studied 94 samples of cachaça and found concentrations ranging from 2.77 to $84.27 \mathrm{mg} 100 \mathrm{~mL}^{-1}$ of anhydrous alcohol.

Table 1. Physicochemical analyses of cachaças for the different varieties of sugarcane used*.

\begin{tabular}{|c|c|c|c|c|c|c|}
\hline Anályses & $\begin{array}{c}\text { Variety } \\
\text { RB 86-7515 (F1) }\end{array}$ & $\begin{array}{c}\text { Variety } \\
\text { SP 83-2847 (F2) }\end{array}$ & $\begin{array}{c}\text { Variety } \\
\text { IAC } 86-2480(\mathrm{~F} 3)\end{array}$ & $\begin{array}{c}\text { Variety } \\
\text { SP 80-3280 (F4) }\end{array}$ & $\begin{array}{c}\text { Variety } \\
\text { CTC } 11 \text { (F5) }\end{array}$ & Established limits \\
\hline $\begin{array}{l}\text { Organoleptic } \\
\text { characteristics }\end{array}$ & $\mathrm{N}$ & $\mathrm{N}$ & $\mathrm{N}$ & $\mathrm{N}$ & $\mathrm{N}$ & \\
\hline Alcohol conc. ${ }^{1}$ & $38.95 \pm 0.290$ (a) & $43.81 \pm 0.141(\mathrm{~b})$ & $38.25 \pm 0.233(\mathrm{a})$ & $46.87 \pm 0.099(c)$ & $45.89 \pm 0.064(\mathrm{~d})$ & $\begin{array}{c}38.0-48.0 \\
38.0-54.0 * *\end{array}$ \\
\hline Volatile acidity $^{2}$ & $48.57 \pm 0.361(\mathrm{a})$ & $33.14 \pm 0.107(b)$ & $34.19 \pm 0.628(b)$ & $12.39 \pm 0.026(c)$ & $30.06 \pm 0.865(\mathrm{~b})$ & $150.0^{* *}$ \\
\hline Esters $^{2}$ & $33.95 \pm 0.801(a)$ & $20.14 \pm 0.309$ (b) & $26.72 \pm 0.987(c)$ & $19.08 \pm 1.325(\mathrm{~b})$ & $23.20 \pm 1.345(\mathrm{c})$ & $200.0^{* *}$ \\
\hline Aldehydes $^{2}$ & $26.48 \pm 2.254(\mathrm{a})$ & $12.15 \pm 0.326(b)$ & $17.47 \pm 1.362(\mathrm{c})$ & $15.70 \pm 0.308(\mathrm{c})$ & $5.91 \pm 0.008(\mathrm{~d})$ & $30.00^{* *}$ \\
\hline Higher alcohols ${ }^{2}$ & $170.8 \pm 0.655(a)$ & $131.3 \pm 0.382(b)$ & $184.07 \pm 1.032(\mathrm{c})$ & $170.80 \pm 1.096(\mathrm{a})$ & $164.22 \pm 0.240(\mathrm{a})$ & $360.00^{* *}$ \\
\hline Copper $^{3}$ & $0.38 \pm 0.008(a)$ & $4.84 \pm 0.132(\mathrm{~b})$ & $1.80 \pm 0.137(\mathrm{c})$ & $0.36 \pm 0.081(\mathrm{a})$ & $0.35 \pm 0.033(\mathrm{a})$ & $5.00^{* *}$ \\
\hline Methanol $^{2}$ & $3.22 \pm 0.008(\mathrm{a})$ & $3.08 \pm 0.008(b)$ & $3.11 \pm 0.008(b)$ & $2.98 \pm 0.008(c)$ & $3.07 \pm 0.008(b)$ & $20.00^{\star *}$ \\
\hline Furfural $^{2}$ & $0.27 \pm 0.035(\mathrm{a})$ & $1.52 \pm 0.029(b)$ & $3.31 \pm 0.174(\mathrm{c})$ & $0.22 \pm 0.012(a)$ & $0.17 \pm 0.007(\mathrm{a})$ & $5.00^{* *}$ \\
\hline Dry matter ${ }^{4}$ & $0.084 \pm 0.010(a)$ & $0.080 \pm 0.007(a)$ & $0.248 \pm 0.001(b)$ & $0.064 \pm 0.004(a)$ & $0.128 \pm 0.001(b)$ & $60.00^{* *}$ \\
\hline Ethyl carbamate ${ }^{3}$ & $4.47 \pm 0.177(\mathrm{a})$ & $32.45 \pm 1.117(\mathrm{c})$ & $2.32 \pm 0.096(a)$ & $49.98 \pm 2.143(\mathrm{c})$ & $9.26 \pm 1.217(b)$ & $210.00^{* * *}$ \\
\hline
\end{tabular}

${ }^{*}$ Mean \pm standard deviation; Means followed by the same letter in the rows are considered equal by the Tukey test $(\alpha=5 \%) ;{ }^{1} \%(\mathrm{v} / \mathrm{v}) ;{ }^{2} \mathrm{mg} 100 \mathrm{~mL}{ }^{-1}$ anhydrous alcohol; ${ }^{3} \mathrm{mg} \cdot \mathrm{L}^{-1} ;{ }^{4} \mathrm{~g} \cdot \mathrm{L}^{-1} ; \mathrm{N}=$ normal; ND = not detected; ${ }^{* *}$ Brazil, 2005; ${ }^{* \star}$ Brazil, 2014. 
The concentrations of the total higher alcohols are within the limits established by MAPA (360 mg $100 \mathrm{~mL}^{-1}$ anhydrous alcohol) for all the samples (Table 1). The higher alcohols are metabolic products resulting from yeast growth. Their formation depends on the conditions of the fermentation medium, the quantity and viability of the inoculum, the temperature, the final alcohol content of the must, among other factors. Depending on the equipment and the distillation process, the content in the final product can vary widely, tending to accumulate up to eight times that of the concentration in the must [15]. According to Cardoso [10], the formation of excess higher alcohols can be avoided by taking some measures, such as not storing the cane for a long period after cutting; avoiding the degradation of amino acids and subsequent formation of the higher alcohols; not using cane from a previous season; and washing the cane after cutting to prevent its contamination by bacteria, which can interfere with the performance of yeasts during fermentation.

None of the samples contained concentrations of copper higher than the legal limit, which is $5 \mathrm{mg} \cdot \mathrm{L}^{-1}$. However, attention is drawn to the F2 sample because it contained a greater concentration that the other samples, and the concentration was very close to the maximum legal limit. No significant difference was observed for mean values of copper in samples F1, F4 and F5. The F1 sample was obtained from a copper still, and the other two from stainless steel stills. For the latter, this result is to be expected because the still does not contain copper in its structure. For the F1 sample, the producer was careful with all the cuts, and periodically decontaminated the still so that the copper concentration met the legal limit. The presence of this metal in the cachaça is mainly due to the dissolution of the basic copper carbonate $\left(\mathrm{CuCO}_{3} \mathrm{Cu}(\mathrm{OH})_{2}\right)$ present on the inner walls of the alembic, which is carried over by the acidic alcohol fumes during the distillation. One way to avoid the excess of this metal in cachaça is to properly sanitize the sugarcane, as well as filling the alembic and the coils with water to reduce the oxidation of copper [10]. The use of ion exchange resin filters is a good alternative for removing the copper from the contaminated beverage without, however, removing secondary components responsible for its sensory quality [16]. Miranda et al. [14] found copper concentrations varying from 0 to $12.25 \mu \mathrm{g} \cdot \mathrm{L}^{-1}$ for 94 different samples produced throughout Brazil.

Methanol is undesirable, not only in cachaça, but also in other alcoholic beverages because of its toxicity, even at low concentrations. The origin of this compound in cachaça is associated with the presence of sugarcane fragments in the fermentation process because degradation of pectin present in sugarcane occurs [10]. According to the current legislation, the maximum limit for this compound is $20 \mathrm{mg} / 100 \mathrm{~mL}$ of anhydrous alcohol. All the samples analyzed contained methanol levels well below those required by the ABPM (Table 1). The results found here corroborate those found by Zacaroni et al. [17] and Miranda et al. [14], who characterized and quantified various concentrations higher than the legal limit. 
All the samples contained furfural concentrations within the legal limit, ranging from 0.17 to $3.31 \mathrm{mg} 100 \mathrm{~mL}^{-1}$ of anhydrous alcohol (Table 1). Furfural is a contaminant that is toxic to the human body and should not be present in cachaça. It is formed mainly during the fermentation process and also during the distillation, especially when it is performed in stills heated directly with fire. Its concentration can increase when the cachaça is aged because of the degradation of pentoses and hemicellulose from the wood of the barrel [10] [18]. Miranda et al. [14] analyzed several samples of cachaça and found mean concentrations ranging from 0 to $1.28 \mathrm{mg} 100 \mathrm{~mL}^{-1}$ of anhydrous alcohol. Subsequently, Cardoso et al. [13] analyzed 54 samples from the state of Minas Gerais and observed furfural concentrations ranging from 0.09 to $21.01 \mathrm{mg} 100 \mathrm{~mL}^{-1}$ of anhydrous alcohol. Thus, producers still exist who do not practice techniques that avoid the excess of furfural.

The dried extract consists of solids present in the cachaça, which can be sugars, cellulosic compounds extracted from the wood in which the beverage was stored and incorporated into it, or even impurities. When the cachaça has a soluble solids content greater than $6 \mathrm{~g} \cdot \mathrm{L}^{-1}$ and as much as $30 \mathrm{~g} \cdot \mathrm{L}^{-1}$, the word "sweetened" should be added to the label [12]. All the samples evaluated had dry extract quantities lower than $6 \mathrm{~g} \cdot \mathrm{L}^{-1}$ (Table 1 ), which was expected because the samples did not undergo any aging, nor were sugars or any other ingredient added to the beverage.

Ethyl carbamate is a compound that is considered to be potentially carcinogenic. In 1985, Canada was the first country to introduce specific legislation regarding this compound, and it established a maximum limit of $150 \mu \mathrm{g} \cdot \mathrm{L}^{-1}$ for distilled beverages. This value became a reference for the United States and the European Community. The compulsory detection and control of ethyl carbamate in cachaça and other distilled sugarcane spirits is of great importance because, in addition to the aspects related to public health, its presence in high concentrations is also a barrier to exportation to Europe and North America [19]. The concentrations of ethyl carbamate found in all the samples of cachaça were within the legal limit in force in the country, that is, below $210 \mu \mathrm{g} \cdot \mathrm{L}^{-1}$, with concentrations varying from 2.32 to $49.98 \mu \mathrm{g} \cdot \mathrm{L}^{-1}$, and a general average of 19.7 $\mu \mathrm{g} \cdot \mathrm{L}^{-1}$. Two samples stood out from the others. They contained the highest concentration: the F2 sample, with $32.45 \mu \mathrm{g} \cdot \mathrm{L}^{-1}$ and the F4 sample, with $49.98 \mu \mathrm{g} \cdot \mathrm{L}^{-1}$. The two samples did not undergo similar productive processes because they were made with different sugarcane varieties, fermentative processes and types of distillation.

Zacaroni et al. [17] analyzed contaminants in samples of cachaça and observed that all the samples contained ethyl carbamate concentrations below the limit established by the Brazilian legislation, and the highest concentration found was $119 \mu \mathrm{g} \cdot \mathrm{L}^{-1}$. d'Ávila et al. [20] evaluated the ethyl carbamate content in cachaça produced with 13 different varieties of sugarcane and different distillation systems (stainless steel column and copper columns). The authors observed 
an average of $24.35 \mu \mathrm{g} \cdot \mathrm{L}^{-1}$, and all the samples were within the legal limits. Mendonça et al. [21] analyzed the concentration of ethyl carbamate in cachaças fermented with selected yeasts and with spontaneously present yeast. As a result, the authors found significant differences in the content of ethyl carbamate that depended on the yeast used. Cachaças containing white rice as a nutrient source for yeast contained higher ethyl carbamate concentrations before and after storage when the production was performed with selected yeast. The authors attributed this fact to the presence of nitrogen-containing compounds in the rice.

These results might help one to understand the data obtained in this study because the samples that contained the highest levels of ethyl carbamate were F2 and F4. The F2 sample was produced by spontaneous fermentation and distilled in a copper alembic. It had a higher alcohol concentration $\left(43.81^{\circ} \mathrm{GL}\right)$ than the other cachaças distilled in copper alembics. These facts indicate that a poor separation of the head and heart fractions occurred, which increased the ethyl carbamate content and the alcohol concentration. The F4 sample was produced with selected yeasts and distilled in a stainless steel column. Its alcohol concentration $\left(49.87^{\circ} \mathrm{GL}\right)$ was higher than those of all the other samples. These results can be attributed to the fact that there is no separation of the fractions in the distillation through stainless steel columns and, consequently, no separation of the first fraction with the volatile components, where, in most cases, a higher concentration of ethyl carbamate is found. According to Aresta et al. [22], the distillation process has remarkable importance among the various production factors that affect the level of ethyl carbamate. However, the F5 sample, produced under the same conditions as F4, but with a different variety of sugarcane, contained a relatively low concentration of ethyl carbamate $\left(9.26 \mu \mathrm{g} \cdot \mathrm{L}^{-1}\right)$, a fact that implies that the sugarcane variety could also be a factor that influences the EC concentration.

\subsection{Characterization of Dhurrin}

The $R_{f}$ values for all the spots observed in the chromatography along with the dhurrin standard are presented in Table 2. In a previous chromatographic analysis of the samples, two spots were only observed with the hexane fraction for all the varieties of sugarcane. Only one spot for all the varieties was observed with the other extracts. The cane varieties RB 86-7515 (F1) and IAC 86-2480 (F3) were the samples whose $R_{f}$ values were the most divergent from the value observed for the dhurrin standard. The other samples had $\mathrm{R}_{\mathrm{f}}$ values similar to or equal to the $\mathrm{R}_{\mathrm{f}}$ of the standard for some extracts.

The $R_{f}$ value for the methanol extract of the SP 80-3280 (F4) sugarcane variety was similar to that of the methanol extract of the standard. Also, the $\mathrm{R}_{\mathrm{f}}$ for the same type of extract of the CTC 11 (F5) variety was similar to that of the standard. Prates et al. [23] identified dhurrin in the methanolic extract isolated from sorghum, data that corroborate those found in this work. The authors, however, did not study other types of extract for the same sample. However, the $\mathrm{R}_{\mathrm{f}}$ (spot 
2) observed for the hexane extract of the SP 83-2847 (F2) sugarcane variety was equal to that of the standard. The relationship of the similarities of the spots and the $R_{f}$ values found for analysis of ethyl carbamate are presented in Table 3 .

The F2 and F4 varieties contained higher concentrations of ethyl carbamate than the remaining samples. The $R_{f}$ values were equal to or similar to the $R_{f}$ value found for the standard. However, there was no similarity in the production of these two varieties. The F2 variety was fermented with wild yeast and distilled in a copper still, whereas the F4 variety was fermented with selected yeast and distilled through a stainless steel column. It was inferred that the fermentation stages with different types of yeast (wild and selected) and different types of distillation (copper still and stainless steel column) did not affect the final concentration of ethyl carbamate.

However, the $\mathrm{R}_{\mathrm{f}}$ values of sample F5 were also similar, but the EC concentration was low when compared to those of the other samples. Thus, there appeared to be no influence of the production process on the final concentration of EC because the same productive process was employed with the two varieties. It can be inferred that the sugarcane variety is a primordial factor in the formation of ethyl carbamate in cachaça.

All the physical and chemical parameters of the cachaças analyzed were within

Table 2. Mean Rf value found for each spot and its respective extract.

\begin{tabular}{cccccc}
\hline $\begin{array}{c}\text { Variety } \\
\text { of sugar cane }\end{array}$ & $\begin{array}{c}\text { Dhurrin } \\
\text { standard }\end{array}$ & $\begin{array}{c}\text { Methanol } \\
\text { extract }\end{array}$ & $\begin{array}{c}\text { Ethyl } \\
\text { acetate } \\
\text { extract }\end{array}$ & $\begin{array}{c}\text { Hexane } \\
\text { extract } \\
\text { (Spot 1) }\end{array}$ & $\begin{array}{c}\text { Hexane } \\
\text { extract } \\
\text { (Spot 2) }\end{array}$ \\
\hline F1 & 0.80 & 0.65 & 0.63 e 0.86 & WS & WS \\
F2 & $\mathbf{0 . 8 0}$ & 0.68 e 0.81 & 0.82 & 0.82 & $\mathbf{0 . 8 0}$ \\
F3 & 0.81 & 0.69 e 0.85 & 0.89 & WS & WS \\
F4 & 0.82 & 0.81 & 0.85 & 0.89 & WS \\
F5 & 0.82 & 0.83 & 0.70 e 0.93 & WS & WS
\end{tabular}

WS $=$ wide spot

Table 3. Similarity between $\mathrm{R}_{\mathrm{f}}$ 's found and the concentration of ethyl carbamate.

\begin{tabular}{|c|c|c|c|}
\hline $\begin{array}{c}\text { Variety } \\
\text { of sugarcane }\end{array}$ & $\begin{array}{l}\text { Dhurrin } \\
\text { standard }\end{array}$ & $\begin{array}{c}R_{f} \text { and type } \\
\text { of extract }\end{array}$ & $\begin{array}{l}\text { Concentration } \\
\text { of EC }\left(\mu \mathrm{g} \cdot \mathrm{L}^{-1}\right)\end{array}$ \\
\hline F1 & 0.80 & No similarity & 4.47 \\
\hline F2 & 0.80 & $\begin{array}{c}0.81 \text { - methanol (spot } 1) \\
0.80 \text { - hexane }(\text { spot } 2)\end{array}$ & 32.45 \\
\hline F3 & 0.81 & No similarity & 2.32 \\
\hline F4 & 0.82 & 0.81 - methanol & 49.98 \\
\hline F5 & 0.82 & 0.83 - methanol & 9.26 \\
\hline
\end{tabular}


the limits required by the Ministry of Agriculture Livestock and Supply, so they are suitable for consumption. The color, odor and characteristic textures of the extracts of the five sugarcane varieties were adequate. The most adequate mobile phase for the TLC of the extracts was the mixture of methyl alcohol and ethyl acetate in the proportion 7:3. The $\mathrm{R}_{\mathrm{f}}$ value observed for the hexane extract of sugarcane variety SP 83-2847 (F2) was equal to that of the dhurrin standard. The $\mathrm{R}_{\mathrm{f}}$ values of the metanol extracts of the SP 80-3280 (F4) and CTC 11 (F5) varieties were similar to that of the standard. The $\mathrm{R}_{\mathrm{f}}$ values for the extracts of the $\mathrm{RB}$ 86-7515 (F1) and IAC 86-2480 (F3) varieties were divergent from the value found for the dhurrin standard. The relevant factor for the final concentration of ethyl carbamate in this study was the variety of sugarcane because no correlation of the concentration of EC in the product with the fermentation and distillation steps was observed.

\section{Acknowledgements}

The authors thank the Conselho Nacional de Desenvolvimento Científico e Tecnológico (CNPQ), the Fundação de Amparo à Pesquisa do Estado de Minas Gerais (FAPEMIG), and the Coordenação de Aperfeiçoamento de Pessoal de Nível Superior (CAPES) for financial support.

\section{Conflicts of Interest}

The authors declare no conflicts of interest regarding the publication of this paper.

\section{References}

[1] Vetter, J. (2000) Plant Cyanogenic Glycosides. Toxicon, 38, 11-36. https://doi.org/10.1016/S0041-0101(99)00128-2

[2] Jones, P.R., Andersen, M.D., Nielsen, J.S., Høj, P.B. and Møller, B.L. (2000) The Biosynthesis, Degradation, Transport and Possible Function of Cyanogenic Glucosides. In: Romeo, J.T., Ibrahim, R., Varin, L. and DeLuca, V., Eds., Evolution of Metabolic Pathways. Recent Advances in Phytochemistry, Pergamon, Amsterdam, Holanda, 191-247. https://doi.org/10.1016/S0079-9920(00)80008-8

[3] Halkier, B.A., Scheller, H.V. and Moller, B.L. (1988) Cyanogenic Glucosides: The Biosynthetic Pathway and the Enzyme System Involved. In: Evered, D. and Harnett, S., Eds., Cyanide Compounds in Biology, John Wiley \& Sons, Chichester, Inglaterra, 49-66.

[4] Coelho, N.R.A. (2014) Noções de higienização na indústria de alimentos. http://wp.ufpel.edu.br/mlaura/files/2014/02/Higieneiza\%C3\%A7\%C3\%A3o-na-ind \%C3\%BAstria-de-alimentos.pdf

[5] Brasil (2005) Ministério da Agricultura, Pecuária e Abastecimento. Instrução Normativa no 24, of September 08, 2005.

[6] Anjos, J.P., Cardoso, M.G., Saczk, A.A., Zacaroni, L.M., Santiago, W.D., Dórea, H.S. and Machado, A.M.R. (2001) Identificação do carbamato de etila durante o armazenamento da cachaça em tonel de carvalho (Quercus sp) e recipiente de vidro. Química Nova, 34, 874-878. https://doi.org/10.1590/S0100-40422011000500025

[7] Machado, A.M.R., et al. (2013) Determination of Ethyl Carbamate in Cachaça Pro- 
duced from Copper Stills by HPLC. Food Chemistry, 138, 1233-1238. https://doi.org/10.1016/j.foodchem.2012.11.048

[8] Santiago, W.D., et al. (2014) Ethyl Carbamate in the Production and Aging of Cachaça in Oak (Quercus sp.) and Amburana (Amburana cearensis) Barrels. Journal Institute of Brewing \& Distilling, 120, 507-511.

[9] Ferreira, D.F. (2011) Sisvar: A Computer Statistical Analysis System. Ciência e Agrotecnologia, 35, 1039-1042. https://doi.org/10.1590/S1413-70542011000600001

[10] Cardoso, M.G. (2013) Análises físico-químicas de aguardente. In Produção de aguardente de cana. Editora Ufla, Lavras, Minas Gerais.

[11] Silva, P.H.A., et al. (2009) Avaliação cromatográfica de compostos voláteis de cachaças produzidas com leveduras de diferentes procedências. Ciência e Tecnologia de Alimentos, 29, 100-106. https://doi.org/10.1590/S0101-20612009000100016

[12] Brasil (2005) Ministério da Agricultura Pecuária e Abastecimento, Instrução Normativa no 13, of June 29, 2005.

[13] Cardoso, M.G., et al. (2012) Cachaça de Minas Gerais/Brasil: Produção e qualidade. Agrotec, 3, 98-101.

[14] Miranda, M.B., et al. (2008) Perfil físico-químico de aguardente durante o envelhecimento em tonéis de carvalho. Ciência e Tecnologia de Alimentos, 28, 84-89. https://doi.org/10.1590/S0101-20612008000500014

[15] Leauté, R. (1990) Distillation in Alembic. American Journal of Enology and Viticulture, 41, 90-103.

[16] Duarte, F.C., et al. (2014) Remoção de cobre em cachaça usando argilas. Ciência e Agrotecnologia, 38, 382-389. https://doi.org/10.1590/S1413-70542014000400009

[17] Zacaroni, L.M., et al. (2011) Caracterização e quantificação de contaminantes em aguardentes de cana. Química Nova, 34, 320-324. https://doi.org/10.1590/S0100-40422011000200026

[18] Pereira, N.E., et al. (2003) Compostos secundários em cachaças produzidas no Estado de Minas Gerais. Ciência e Agrotecnologia, 27, 1068-1075. https://doi.org/10.1590/S1413-70542003000500014

[19] Andrade-Sobrinho, L.G., et al. (2002) Carbamato de etila em bebidas alcoólicas (cachaça, tiquira, uísque e grapa). Química Nova, 25, 1074-1077. https://doi.org/10.1590/S0100-40422002000700005

[20] d'Ávila, G.B., et al. (2016) Quantification of Ethyl Carbamate in Cachaça Produced in Different Agro-Industrial Production Systems. Journal Institute of Brewing \& Distilling, 122, 299-303. https://doi.org/10.1002/jib.322

[21] Mendonça, J.G., et al. (2016) Determination of Ethyl Carbamate in Cachaças Produced by Selected Yeast and Spontaneous Fermentation. Journal Institute of Brewing \& Distilling, 122, 63-68. https://doi.org/10.1002/jib.308

[22] Aresta, M., et al. (2001) Cooper (II) Catalysis in Cyanide Conversion into Ethyl Carbamate in Spirits and Relevant Reactions. Journal of Agricultural and Food Chemistry, 49, 2819-2824. https://doi.org/10.1021/jf001346w

[23] Prates, H.T., et al. (1996) Extração, isolamento e caracterização de dhurrin em sorgo sem tanino resistente a pássaro. Congresso Nacional de Milho e Sorgo, IAPAR, Londrina, 1-261. 